\title{
Hydrogeothermal modelling vs. inorganic chemical composition of thermal waters from the area of Carballiño (NW Spain)
}

\author{
I. Delgado-Outeiriño ${ }^{1}$, P. Araujo-Nespereira ${ }^{1}$, J. A. Cid-Fernández ${ }^{1}$, J. C. Mejuto ${ }^{2}$, E. Martínez-Carballo ${ }^{3}$, and \\ J. Simal-Gándara ${ }^{3}$ \\ ${ }^{1}$ Geodynamics Group, Marine Geo-science and Territory Rationalization Department, \\ Faculty of Food Science and Technology, University of Vigo, Ourense Campus, 32004 Ourense, Spain \\ ${ }^{2}$ Physical-Chemistry Department, Faculty of Food Science and Technology, University of Vigo, \\ Ourense Campus, 32004 Ourense, Spain \\ ${ }^{3}$ Nutrition and Bromatology Group, Analytical and Food Chemistry Department, \\ Faculty of Food Science and Technology, University of Vigo, Ourense Campus, 32004 Ourense, Spain
}

Correspondence to: J. Simal-Gándara (jsimal@uvigo.es)

Received: 29 March 2011 - Published in Hydrol. Earth Syst. Sci. Discuss.: 5 May 2011 Revised: 30 December 2011 - Accepted: 9 January 2012 - Published: 13 January 2012

\begin{abstract}
Hydrothermic features in Galicia (northwest Spain) have been used since ancient times for therapeutic purposes. A characterization of these thermal waters was carried out in order to understand their behaviour based on inorganic pattern and water-rock interaction mechanisms. In this way 15 thermal water samples were collected in the same hydrographical system. The selected thermal water samples were classified using principal component analysis (PCA) and partial least squares (PLS) regression analysis in two groups according to their chemical composition: group I with the young water samples and group II with the samples with longest water-rock contact time. This classification agreed with the results obtained by the use of geothermometers and hydrogeochemical modelling, where the samples were classified into two categories according their residence time in the reservoir and their water-rock interaction.
\end{abstract}

\section{Introduction}

Galicia, in northwest Spain and with an area of $29574 \mathrm{~km}^{2}$, is bordered by Portugal to the south, the Spanish regions of Castile and León and Asturias to the east, the Atlantic Ocean to the west, and the Bay of Biscay to the north. Galicia was affected by the hercynian orogeny and in this region, materials of Proterozoic and the Palaeozoic outcrops are affected by major faults. This Hesperian massif has emerged since the end of the Paleozoic and erosion has exposed important granite batholites.
Galicia has vast thermal groundwater resources with therapeutic uses in its subsoil, as there are more than three hundred sources registered, of which twenty are used by spas (Dirección Xeral de Industria, Enerxía e Minas, 2003; Regional Government of Galicia, 2011). The use of thermal waters in Galicia, for therapeutic means, dates back to Roman times. During the nineteenth century the thermal baths experienced a golden age, with several spas, but at the end of this century a long crisis began. At present more emphasis is being placed on their recreational and aesthetic aspects than on their curative potential. Recently, Ourense was designated by the Galician Regional Parliament as the Thermal Capital of Galicia due to their therapeutic hot springs, representing the second highest position in thermal water of the Iberian Peninsula.

Most of these sources reach the highest water temperatures in Spain of about $71^{\circ} \mathrm{C}$. The abundance of these springs in Galicia is associated with the lithologic type and the soil fracturation.

The chemistry of thermal waters has attracted the attention of numerous studies to understand the processes that influence the aquifer recharge to estimate its resource importance and potential exploitation. In this way, some studies have been developed with the thermal waters of the area of Ourense city, the Thermal Capital of Galicia due to their therapeutic hot springs (González-Barreiro et al., 2009; DelgadoOuteiriñoet al., 2009). 


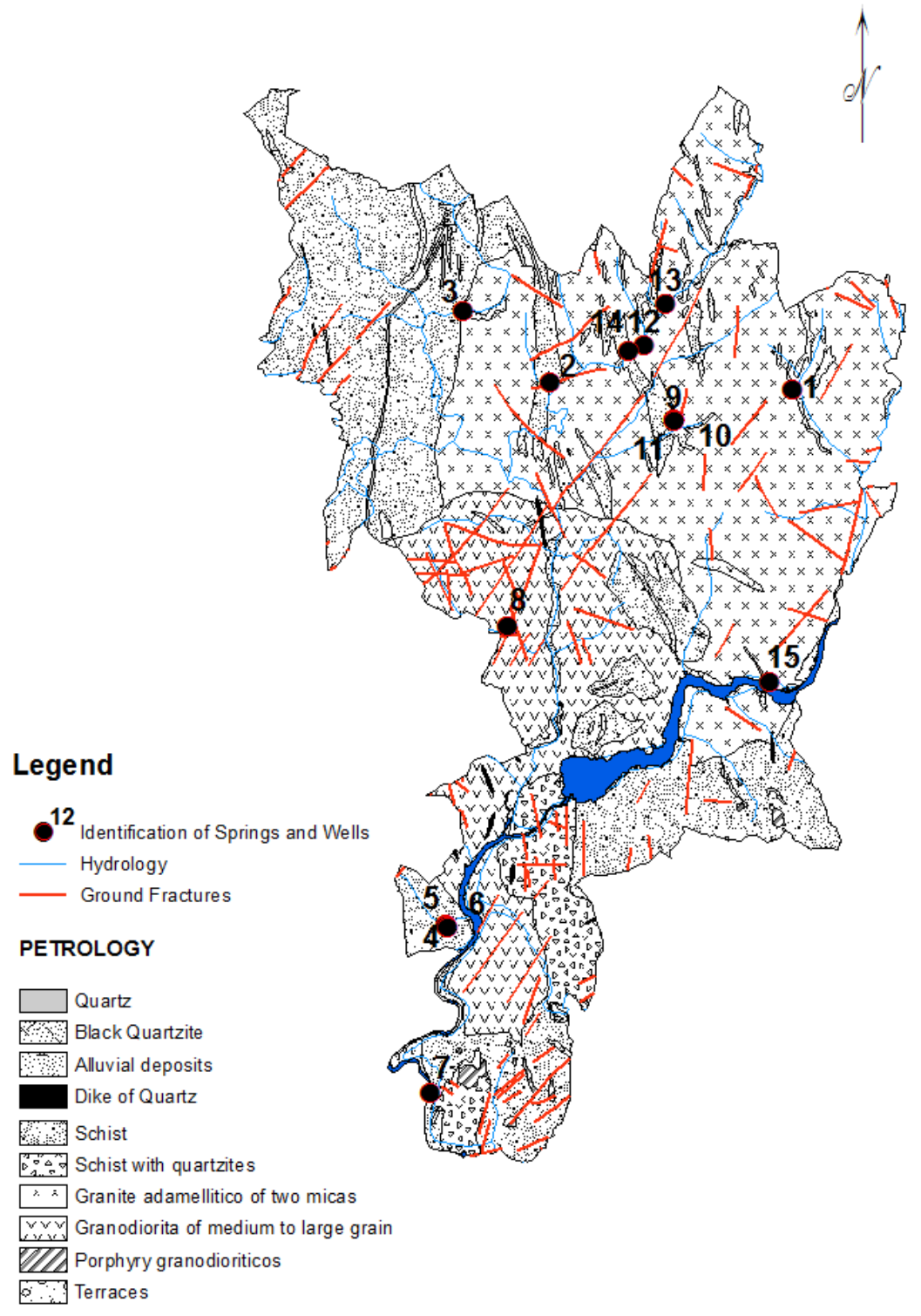

Fig. 1. Geological map with the sampling sites.

Carballiño is a municipality in the Spanish province of Ourense and has an area of $54 \mathrm{~km}^{2}$. It has famous thermal spas together with multiple streams that bathe the countryside.

With the renewed interest in thermomineral waters, the principal aim of this study was to characterize the chemical equilibrium state of waters from Carballiño, as well as the thermodynamic conditions influencing water-rock interaction. As a secondary line of interest, this study aims to determine the temperature of the water within the reservoir.

\section{Experimental set-up}

\subsection{Geochemical and hydrogeological setting}

From the geological point of view, Carballiño is situated on a granite crystalline substrate, which could be divided into two study areas, Northeast and Southwest (Fig. 1). The North Eastern part consists of schist with granitic injections and two-mica granite rocks of adamellites, in which several intrusions of gneiss and schist are present. It is in this area where 10 of the 15 selected thermal waters (1-2-3-9-10-1112-13-14-15) are located. Upwelling of these waters would occur in areas of contact between granite rocks and metamorphic materials (schists). This granitic material is closely associated with metamorphism and migamtization. The granite 
Table 1. Sampling sites, and in-site (pH, $T$ and C) and laboratory measurements of the 15 thermal water samples.

\begin{tabular}{|c|c|c|c|c|c|c|c|c|c|c|c|c|c|c|c|c|c|}
\hline Locality & UTM & UTM & Height & $\mathrm{pH}$ & $T$ & $\mathrm{C}$ & $\mathrm{Na}^{+}$ & $\mathrm{Li}^{+}$ & $\mathrm{K}^{+}$ & $\mathrm{Rb}^{+}$ & $\mathrm{Ca}^{+2}$ & $\mathrm{Mg}^{+2}$ & $\mathrm{Sr}^{+2}$ & $\mathrm{Fe}^{+2}$ & $\mathrm{Zn}^{+2}$ & B & WH \\
\hline (sample no) & (H29) X & (H29) Y & $(\mathrm{m})$ & & ${ }^{\circ} \mathrm{C}$ & $\mu \mathrm{S} \mathrm{cm}^{-1}$ & $\mathrm{mg} \mathrm{l}^{-1}$ & $\mathrm{mg} 1^{-1}$ & $\mathrm{mg}^{-1}$ & $\mathrm{mg} 1^{-1}$ & $\mathrm{mg} 1^{-1}$ & $\mathrm{mg}^{-1}$ & $\mathrm{mg} 1^{-1}$ & $\mathrm{mg} 1^{-1}$ & $\mathrm{mg}^{-1}$ & $\mathrm{mg} 1^{-1}$ & \\
\hline A Rañoa (1) & 580734 & 4696805 & 352 & 8.72 & 21 & 163 & 40 & 0.15 & 0.94 & 0.080 & 6.4 & 0.21 & 0.10 & 0.020 & 0.070 & 0.26 & 26 \\
\hline Ponterriza (2) & 572372 & 4697055 & 345 & 8.0 & 17 & 185 & 43 & 0.15 & 1.2 & 0.050 & 5.0 & 0.58 & 0.090 & 0.030 & 0.42 & 0.38 & 20 \\
\hline Brues (3) & 569378 & 4699511 & 342 & 8.28 & 27 & 196 & 43 & 0.26 & 1.4 & 0.030 & 9.2 & 0.52 & 0.14 & 0.020 & 0.090 & 0.23 & 31 \\
\hline Prexigueiro I (4) & 568802 & 4678390 & 122 & 8.72 & 44 & 363 & 56 & 0.57 & 3.0 & 0.080 & 4.0 & 0.25 & n.d. & n.d. & 0.18 & 0.63 & 14 \\
\hline Prexigueiro II (5) & 568794 & 4678375 & 122 & 8.44 & 29 & 367 & 65 & 0.66 & 3.5 & 0.070 & 3.4 & 0.17 & 0.060 & 0.020 & 0.21 & 0.91 & 11 \\
\hline Prexigueiro III (6) & 568800 & 4678388 & 122 & 8.30 & 30 & 369 & 72 & 0.77 & 3.6 & 0.070 & 3.4 & 0.060 & n.d. & 0.040 & 0.25 & 0.70 & 12 \\
\hline Cortegada Baños (7) & 568265 & 4672622 & 92 & 9.27 & 40 & 456 & 73 & 1.1 & 3.5 & 0.070 & 3.2 & 0.050 & n.d. & 0.040 & 0.25 & 1.5 & 14 \\
\hline Beran Balneario (8) & 570892 & 4688652 & 161 & 7.73 & 27 & 279 & 58 & n.d. & 1.0 & n.d. & 5.0 & n.d. & n.d. & 0.50 & n.d. & n.d. & 13 \\
\hline Partovia I (9) & 576648 & 4695756 & 335 & 9.42 & 37 & 175 & 46 & 0.17 & 1.0 & 0.060 & 3.2 & n.d. & 0.10 & n.d. & 0.19 & 0.33 & 13 \\
\hline Partovia II (10) & 576648 & 4695764 & 335 & 9.28 & 31 & 179 & 45 & 0.17 & 1.0 & 0.080 & 3.4 & n.d. & 0.10 & n.d. & 0.080 & 0.24 & 14 \\
\hline Partovia III (11) & 576660 & 4695739 & 335 & 9.19 & 22 & 195 & 45 & 0.18 & 1.1 & 0.11 & 3.2 & 0.030 & 0.10 & n.d. & 0.11 & 0.36 & 16 \\
\hline Gran Balneario (12) & 575615 & 4698320 & 412 & 9.15 & 26 & 258 & 52 & 0.47 & 2.8 & 0.11 & 3.9 & n.d. & 0.070 & 0.010 & 0.090 & 0.71 & 31 \\
\hline Arcos Carballiño (13) & 576354 & 4699769 & 545 & 9.01 & 17 & 254 & 54 & 0.48 & 2.3 & 0.060 & 2.2 & 0.040 & 0.080 & 0.060 & 0.070 & 0.23 & 16 \\
\hline O Xardín (14) & 575070 & 4698131 & 380 & 7.19 & 13 & 137 & 51 & n.d. & 1.2 & n.d. & 14 & 11 & n.d. & 0.020 & 0.010 & 0.11 & 24 \\
\hline Laias Balneario (15) & 579921 & 4686739 & 95 & 7.99 & 46 & 629 & 97 & 0.96 & 6.6 & 0.13 & 6.2 & 0.38 & 0.090 & n.d. & 0.32 & 0.75 & 20 \\
\hline
\end{tabular}

UTM: Universal Transverse Mercator coordinates; WH: Water hardness; DR: Dry resiude; C: electrical conductivity.

Table 1. Continued.

\begin{tabular}{|c|c|c|c|c|c|c|c|c|c|c|c|c|c|c|c|c|}
\hline Locality & UTM & UTM & $\mathrm{Cl}^{-}$ & $\mathrm{NH}^{+4}$ & $\mathrm{~F}^{-}$ & $\mathrm{CO}_{3}^{-}$ & $\mathrm{Si}$ & $S^{-2}$ & $\mathrm{CO}_{3} \mathrm{H}^{-}$ & $\mathrm{Cs}^{+}$ & $\mathrm{Al}^{+2}$ & $\mathrm{SO}_{4}^{-2}$ & $\mathrm{NO}_{3}^{-}$ & $\mathrm{NO}_{2}^{-}$ & $\mathrm{PO}_{4}^{-3}$ & DR \\
\hline (sample no) & (H29) X & (H29) Y & $\mathrm{mg} 1^{-1}$ & $\mathrm{mg}^{-1}$ & $\mathrm{mg} 1^{-1}$ & $\mathrm{mg}^{-1}$ & $\mathrm{mg} 1^{-1}$ & $\mathrm{mg} 1^{-1}$ & $\mathrm{mg} \mathrm{1^{-1 }}$ & $\mathrm{mg} 1^{-1}$ & $\mathrm{mg}^{-1}$ & $\mathrm{mg} 1^{-1}$ & $\mathrm{mg}^{-1}$ & $\mathrm{mg}^{-1}$ & $\mathrm{mg}^{-1}$ & \\
\hline A Rañoa (1) & 580734 & 4696805 & 9.5 & 0.78 & 5.8 & 10 & 26 & 0.23 & 60 & 11 & 49 & 8.0 & 0.13 & n.d. & 0.24 & 162 \\
\hline Ponterriza (2) & 572372 & 4697055 & 11 & 1.4 & 8.3 & 14 & n.d. & n.d. & 60 & 19 & 35 & 7.0 & 0.91 & n.d. & 0.79 & 100 \\
\hline Brues (3) & 569378 & 4699511 & 14 & 1.6 & 7.0 & 14 & 33 & 1.3 & 57 & 28 & 18 & 16 & 0.43 & n.d. & 0.22 & 176 \\
\hline Prexigueiro I (4) & 568802 & 4678390 & 23 & 2.9 & n.d. & 33 & 54 & 0.71 & 73 & 49 & 60 & 16 & 0.37 & 0.035 & 0.21 & 288 \\
\hline Prexigueiro II (5) & 568794 & 4678375 & 25 & 2.8 & 15 & 31 & 44 & n.d. & 112 & 83 & 44 & 38 & 0.61 & 0.012 & 0.080 & 352 \\
\hline Prexigueiro III (6) & 568800 & 4678388 & 25 & 4.1 & 16 & 30 & 50 & 0.40 & 100 & 50 & 52 & 24 & 0.55 & 0.025 & 0.15 & 300 \\
\hline Cortegada Baños (7) & 568265 & 4672622 & 29 & 5.7 & 15 & 57 & 42 & 0.25 & 116 & 64 & 74 & 16 & n.d. & n.d. & 0.56 & 376 \\
\hline Beran Balneario (8) & 570892 & 4688652 & 16 & 0.16 & n.d. & n.d. & n.d. & n.d. & 89 & n.d. & n.d. & 19 & n.d. & n.d. & 0.16 & 240 \\
\hline Partovia I (9) & 576648 & 4695756 & 11 & 1.4 & 5.9 & 36 & 31 & 0.080 & 47 & 13 & 98 & 10 & n.d. & n.d. & 0.33 & 169 \\
\hline Partovia II (10) & 576648 & 4695764 & 11 & 1.6 & 5.5 & 21 & 32 & 0.13 & 56 & 16 & 49 & 10 & n.d. & n.d. & 0.39 & 173 \\
\hline Partovia III (11) & 576660 & 4695739 & 12 & 1.5 & 5.3 & 23 & 25 & 0.10 & 57 & 8,6 & 39 & 11 & 0.050 & n.d. & 0.18 & 170 \\
\hline Gran Balneario (12) & 575615 & 4698320 & 13 & 3.6 & 11 & 47 & 41 & 0.25 & 62 & 23 & 34 & 13 & n.d. & n.d. & 0.090 & 219 \\
\hline Arcos Carballiño (13) & 576354 & 4699769 & 15 & 3.6 & 9.9 & 32 & 36 & 0.040 & 66 & 28 & 46 & 11 & n.d. & n.d. & 0.40 & 238 \\
\hline O Xardín (14) & 575070 & 4698131 & 9.3 & n.d. & 4.2 & 11 & 21 & 2.1 & 51 & n.d. & n.d. & 9.2 & 0.21 & n.d. & 0.18 & 24 \\
\hline Laias Balneario (15) & 579921 & 4686739 & 24 & 1.2 & 12 & n.d. & 51 & 0.16 & 366 & 49 & 70 & 4.0 & 0.070 & n.d. & 0.64 & 543 \\
\hline
\end{tabular}

rocks of adamellites should be formed by anatexis in deeper areas, when the main Hercynian metamorphism reached the maximum temperature.

The most abundant rock material in the Southwest area is one of the most common facies of granite, medium- to coarse-grained porphyritic granodiorite, which is composed of quartz, feldspar, plagioclase, muscovite and biotitic. Only one of the 15 thermal waters is located here, Beran Spa (8), with a temperature of $27^{\circ} \mathrm{C}$ (Table 1 ). The rest of the selected thermal waters are related with the schistose material found in this area (4-5-6-7) with the highest temperatures $\left(>40^{\circ} \mathrm{C}\right)$.

The macro-fracturation of this area is represented by two large families of fractures that interact with each other. These families correspond to fracture $\mathrm{N} 20^{\circ} \mathrm{W}$ and $\mathrm{N} 130^{\circ} \mathrm{W}$. These two families of fractures even within the same structural system, have a different behavior. The first one $\left(\mathrm{N} 20^{\circ} \mathrm{W}\right)$ consists in major fractures in terms of size and scope, and affects mainly the territory, acting as tear fractures (translations). The second family $\mathrm{N} 130^{\circ} \mathrm{W}$, is complemen- tary to the first one within the same effort, but those are extensional in nature, favoring percolation, circulation and delivery of water. For this work we have analyzed only springs and therefore, no data are available about some parameters such as hydraulic conductivity, groundwater level, because in the study area there are no water wells to determine those characteristics. The Adense river network uses the lineation of these structures, as well as does the Miño river and its tributaries. For this reason, the thermal circuit is determined by the intense subsoil fracture network, causing the rise of the hot springs through an opening in the Earth's surface. The water appears on the surface when they reach the piezometric level; specifically in this area a contact between the granitic and metamorphic substrates takes places. They are also the lowest altitude levels in the study area.

\subsection{Sampling procedure in thermal water sites}

In this study 15 thermal water samples were collected in April 2008 (Table 1).Water samples were collected by immersing amber glass bottles at the points of emission. All 


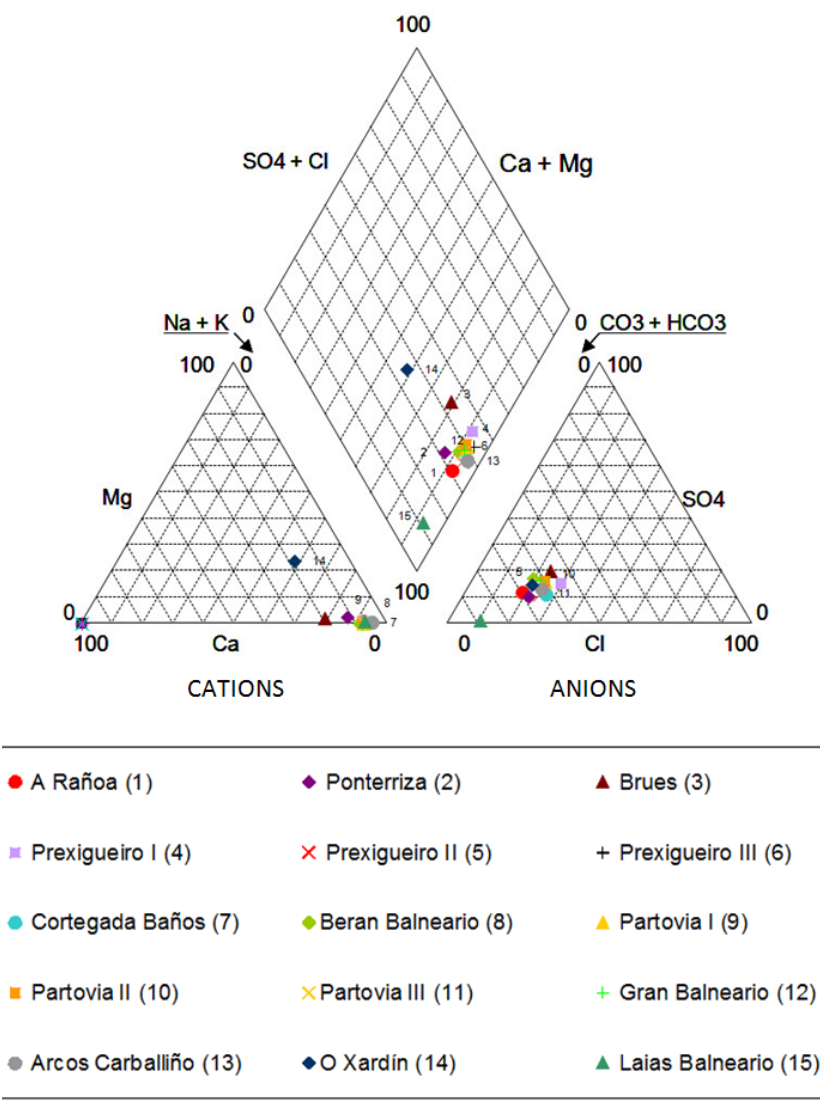

Fig. 2. Hill-Piper diagram of the 15 selected waters from Carballiño. The analytical data represented in the diagram correspond to the sampling campaign on April 2008.

samples were filtered ( 0.45 micron) and placed in a portable cooler, with ice, immediately after collection to prevent bio alteration; in the laboratory, they were transferred and stored at $4{ }^{\circ} \mathrm{C}$ until analysis within the next $24 \mathrm{~h}$. Per site, two samples were collected: one for the analysis of cations (acidified with $\mathrm{HNO}_{3}$ to $\mathrm{pH}$ lower than (2), and the other for anions.

\subsection{Chemical analysis}

Temperature, $\mathrm{pH}$ and electrical conductivity of waters were measured in the field. Aluminium, boron, caesium, strontium and zinc were determined by Inductively Coupled Plasma Mass Spectrometry (Thermo X series II ICP-MS). Calcium, iron, magnesium and manganese were measured by atomic absorption spectrophotometry (Varian SpectrAA-250 Plus). Lithium, sodium and potassium were analysed by atomic emission spectrophotometry (Varian SpectrAA-250 Plus). Chloride, fluoride, sulphur, nitrite, nitrate, ammonium, phosphate and sulphate anions were determined by capillary electrophoresis (Thermo Capillary Electrophoresis using UV/Vis detector Cristal 100). Bicarbonate was determined by acidimetric titration. Analytical errors are generally $<5 \%$ for the main components.
Table 2. Some ionic ratios (in meq $1^{-1}$ ) of interest in the selected thermal waters.

\begin{tabular}{lrrr}
\hline & $\begin{array}{r}\mathrm{Cl}^{-} / \\
\mathrm{SO}_{4}^{-2}\end{array}$ & $\begin{array}{r}\mathrm{Cl}^{-} / \\
\mathrm{HCO}_{3}^{-}\end{array}$ & $\begin{array}{r}\left(\mathrm{Cl}^{-}+\mathrm{SO}_{4}^{-2}\right) / \\
\mathrm{HCO}_{3}^{-}\end{array}$ \\
\hline A Rañoa (1) & 3.2 & 0.27 & 0.36 \\
Ponterriza (2) & 4.3 & 0.32 & 0.39 \\
Brues (3) & 2.3 & 0.42 & 0.59 \\
Prexigueiro I (4) & 3.9 & 0.54 & 0.68 \\
Prexigueiro II (5) & 1.8 & 0.38 & 0.60 \\
Prexigueiro III (6) & 2.3 & 0.40 & 0.61 \\
Cortegada Baños (7) & 4.8 & 0.42 & 0.51 \\
Beran Balneario (8) & 2.3 & 0.31 & 0.44 \\
Partovia I (9) & 2.8 & 0.38 & 0.52 \\
Partovia II (10) & 2.9 & 0.33 & 0.44 \\
Partovia III (11) & 2.8 & 0.35 & 0.47 \\
Gran Balneario (12) & 2.7 & 0.36 & 0.49 \\
Arcos Carballiño (13) & 3.6 & 0.38 & 0.49 \\
O Xardín (14) & 2.7 & 0.31 & 0.43 \\
Laias Balneario (15) & 3.2 & 0.32 & 0.45 \\
\hline
\end{tabular}

\subsection{Thermal water chemistry}

The combined use of $\mathrm{Cl}^{-} / \mathrm{SO}_{4}^{-2}, \quad \mathrm{Cl}^{-} / \mathrm{HCO}_{3}^{-}$and $\left(\mathrm{Cl}^{-}+\mathrm{SO}_{4}^{-2}\right) / \mathrm{HCO}_{3}^{-}$and the Hill-Piper diagram (Piper, 1944) led to an improved classification of the thermal water samples.

The statistical methods used for data analysis of the samples were principal component analysis (PCA) and partial least squares regression (PLS-regression) (López-Chicano et al., 2001; Cruz and França., 2006; Cerón et al., 1999). The PC model was calculated on the auto scaled (namely, columns were mean-centred and scaled to unit variance) data. This was done to focus the analysis on in-between sample variations and unify the importance of each variable independently of the concentration levels. The model was further validated by cross-validation, visual inspection of loadings, and chemical interpretation to ascertain the presence of a meaningful interpretation for the PCA. The method of regression by PLS has been used extensively in chemometrics, where they have found a wide field of application. To attach a weighting to each variable, the data obtained were divided by the standard deviation of each series and later processed by means of PLS2 algorithm of the Unscrambler program, utilizing the method of "cross validation". "Leverage correction" validation method may result in over-optimistic validation results. Statistical analysis was carried out using the following statistical programmes: Unscrambler version 9.1 (Camo Process AS, 2004) and Statgraphics version 5.1 both for Windows. 


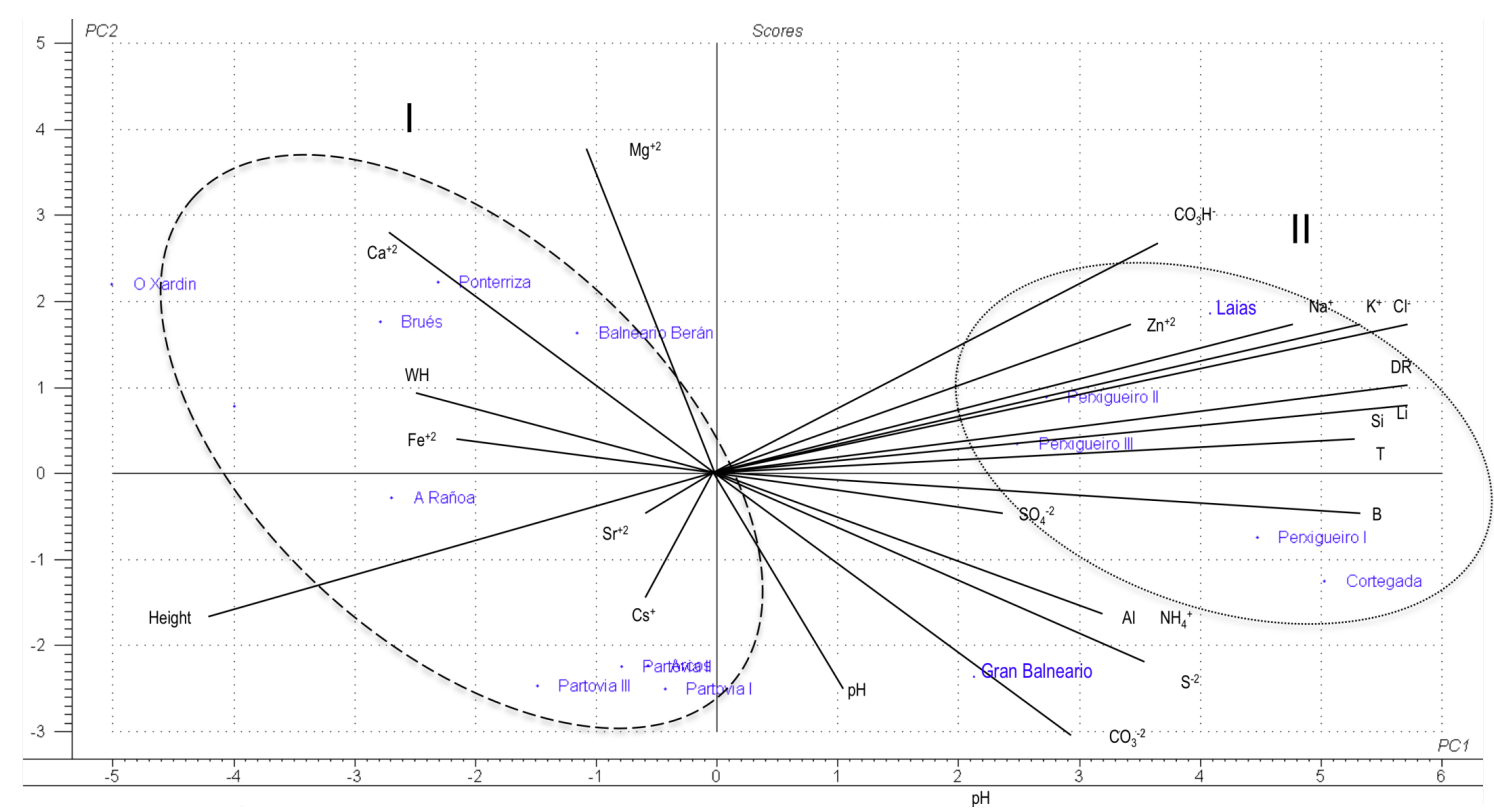

Fig. 3. Prinicpal component analysis on the selected thermal waters. Cluster I, samples with the shortest water-rock contact time, lowest equilibrium temperatures and under-saturated with respect to calcite. Cluster II, samples with longest water-rock contact time, highest equilibrium temperature and super-saturated with respect to calcite.

\subsection{Geothermometers and hydrogeochemical modelling}

Silica Geothermometers were used to obtain the most precise data possible about the theoretical reservoir temperature of our system and it was carried out using the thermodynamic database WATEQ4F.dat (Ball and Nordstrom, 2001) included in the PHREEQC package (Parkhurst et al., 1980). The PHREEQC package was also used for the geothermometric modelling.

\section{Results and discussion}

\subsection{Chemical composition of waters and ionic ratios}

The measurements taken on thermal waters are reported in Table 1. Values of pH range from 7.2 to 9.4, indicating alkaline thermal waters (Delgado-Outeiriño et al., 2009; López-Chicano et al., 2001). Anions are mostly represented by $\mathrm{CO}_{3} \mathrm{H}^{-}\left(47-366 \mathrm{mgl}^{-1}\right)$, followed by $\mathrm{CO}_{3}^{-2}$ (n.d.$\left.57 \mathrm{mg} \mathrm{l}^{-1}\right), \mathrm{Cl}^{-}\left(9.3-29 \mathrm{mg} \mathrm{l}^{-1}\right), \mathrm{SO}_{4}^{-2}\left(4.0-38 \mathrm{mg} \mathrm{l}^{-1}\right), \mathrm{F}^{-}$ (n.d. $-16 \mathrm{mgl}^{-1}$ ) and $\mathrm{NO}_{3}^{-}$(n.d. $-0.91 \mathrm{mgl}^{-1}$ ). Among the cations, $\mathrm{Na}^{+}$is the main dissolved species (40-97 mg ${ }^{-1}$ ), followed mainly by $\mathrm{Ca}^{+2}\left(2.2-14 \mathrm{mgl}^{-1}\right)$ and $\mathrm{K}^{+}(0.94-$ $\left.6.6 \mathrm{mg} \mathrm{l}^{-1}\right)$. Temperature varies between $13{ }^{\circ} \mathrm{C}$ and $46^{\circ} \mathrm{C}$. The electrical conductivity ranges from 137 to $629 \mu \mathrm{S} \mathrm{cm}^{-1}$ ). A general analysis of the inorganic pattern of the selected waters reveals in the distinction of only one type of waters as Fig. 2 shows: sodium-bicarbonated waters. Galicia was affected by the hercynian orogeny and these water types occur in the internal areas of post-orogenic fracture zones.

Moreover, a PCA was carried out to reduce the structure of the data set to two dimensions. The total variance explained by these two components accounts for $69 \%$ (42\% PC1 and $27 \%$ PC2) of the variability of the data (Fig. 3).The third principal component accounts for $12 \%$ of the variability and although it could also be used to explain our model, we use only two principal components because they are placed along directions of maximum variance. It means that these two PCs give the clearest break point in the total residual variance plot and we do not include more PCs because their small variances could correspond to noise. The two clusters (Fig. 3) are explained by various factors (chemical and physical water properties). Cluster I is clearly distinct from the other, mainly by their higher $\mathrm{Ca}^{+2}, \mathrm{Mg}^{+2}, \mathrm{Fe}^{+2}$, water hardness and altitude. The sequence $\mathrm{Ca}^{+2}>\mathrm{Mg}^{+2}>\mathrm{Na}^{+}$is similar to the general depth sequence for groundwater composition outlined by Chebotarev (1955). When $\mathrm{Ca}^{+2}>\mathrm{Mg}^{+2}>\mathrm{Na}^{+}$ it means that young/surface water is present. A young fraction in a confined aquifer suggests possible modern recharge, continuity with surface/shallow waters, or mixing of young and old water. The cluster II contains the water samples that are distinguished due to their temperature, $\mathrm{S}^{-2}, \mathrm{SO}_{4}^{-2}, \mathrm{Si}$, $\mathrm{Li}, \mathrm{Na}^{+}$and dry residue contents. In this cluster, the springs belong to Prexigueiro I, II, III, Cortegada and Laias.

Several ratios between different elements were also investigated and the most interesting results were observed between $\mathrm{Cl}^{-} / \mathrm{SO}_{4}^{-2}, \mathrm{Cl}^{-} / \mathrm{HCO}_{3}^{-}$and $\left(\mathrm{Cl}^{-}+\mathrm{SO}_{4}^{-2}\right) / \mathrm{HCO}_{3}^{-}$(Table 2). The $\mathrm{Cl}^{-} / \mathrm{SO}_{4}^{-2}$ ratio shows the interaction between 

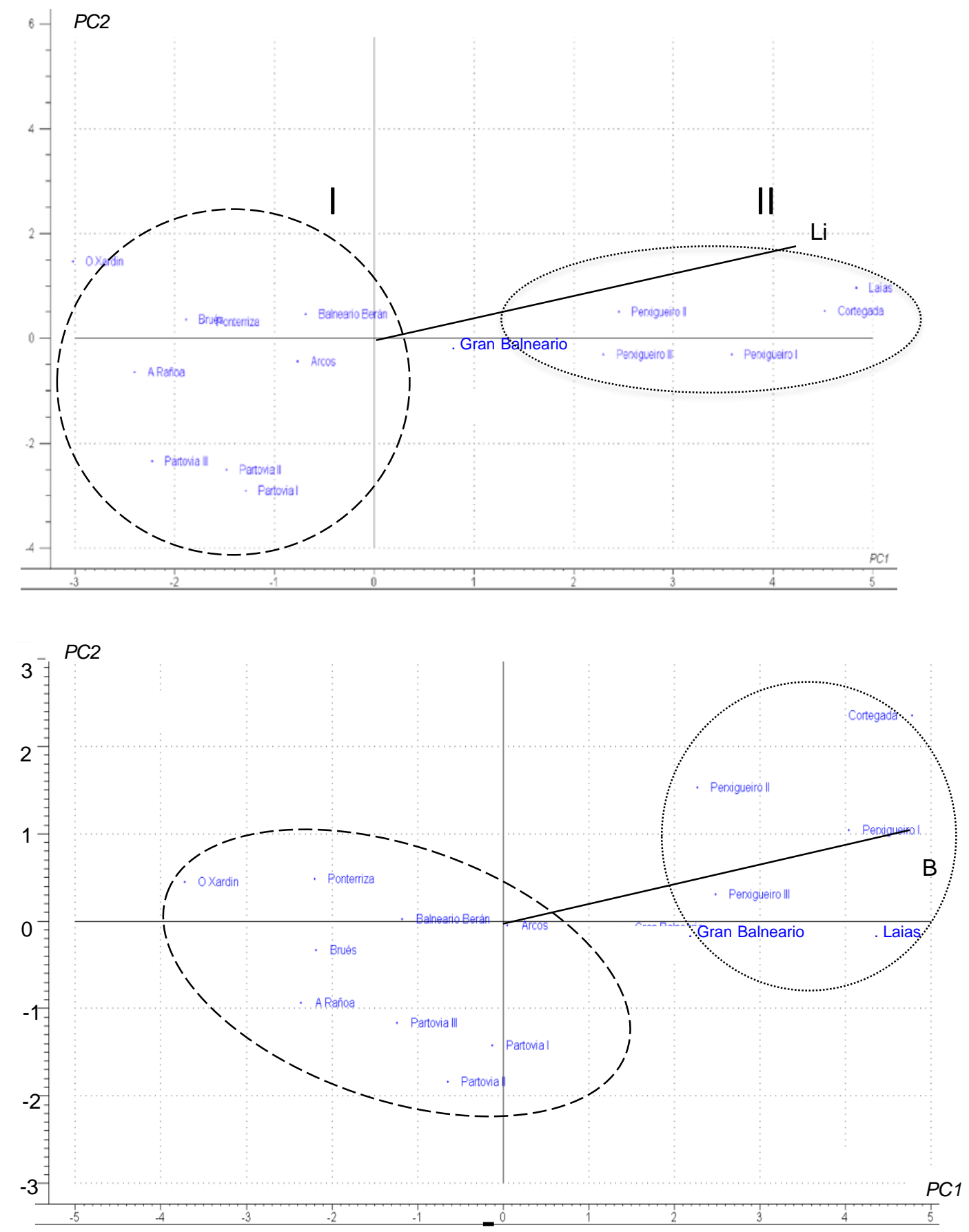

Fig. 4. Partial Least-squares regression plots for the selected samples, showing the $\mathrm{X}$ loading weights and the $\mathrm{Y}$ loadings for Li and $\mathrm{B}$. Regression coefficient of 0.9988 and 0.8996 for Li and B are obtained. Two clusters are also distinguised depending on Li and B contents.

water and rock (López-Chicano et al., 2001); a higher ratio value would indicate that this water remained over a much longer period in the ground and therefore interacted with the rock. The same conclusion could be drawn with respect to the spatial evolution of the $\mathrm{Cl}^{-} / \mathrm{HCO}_{3}^{-}$and $\left(\mathrm{Cl}^{-}+\mathrm{SO}_{4}^{-2}\right) / \mathrm{HCO}_{3}^{-}$ratios (López-Chicano et al., 2001).
The elevated mobility of Lithium is related to temperature (Chan et al., 1994). It is found in high concentrations in thermal waters, and for this reason it is a good tracer for geochemical investigations of hydrothermal systems (Brondi et al., 1973, 1983). The concentration of Lithium in water depends also on the water-rock contact time (Fidelibus and Tulipano, 1990) and, therefore, Lithium content could 
Table 3. Quartz, chalcedony, kaolinite and k-mika equilibrium temperatures $\left({ }^{\circ} \mathrm{C}\right)$ using the thermodynamic database (Ball and Nordstrom, 2001). Equilibrium temperatures $(T)$ for the geothermometers of $\mathrm{SiO}_{2}$-quartz and chalcedony are also shown.

\begin{tabular}{|c|c|c|c|c|c|c|c|}
\hline Samples $\left(\right.$ samplen $^{\circ}$ ) & Quartz & Chalcedony & Kaolinite & K-mica & $\mathrm{T}_{-} \mathrm{SiO}_{2}$-quartz & $\mathrm{T}$ - $\mathrm{SiO}_{2}$-chalcedony & Group \\
\hline A Rañoa (1) & 73 & 41 & 41 & & 73 & 41 & I \\
\hline Ponterriza (2) & 73 & 58 & 60 & 97 & 80 & 49 & I \\
\hline Brues (3) & 82 & 52 & & & 83 & 52 & I \\
\hline Prexegueiro I (4) & 101 & 65 & 56 & 82 & 95 & 65 & II \\
\hline Prexigueiro II (5) & 97 & 67 & 58 & 85 & 92 & 62 & II \\
\hline Prexigueiro III (6) & 103 & 70 & 55 & 94 & 95 & 62 & II \\
\hline Cortegada (7) & 82 & 70 & 70 & 72 & 92 & 64 & II \\
\hline Beran (8) & 70 & 40 & 63 & 81 & 72 & 40 & I \\
\hline Partovia I (9) & 63 & 42 & 35 & 65 & 70 & 48 & I \\
\hline Partovia II (10) & 75 & 45 & 40 & 70 & 72 & 50 & I \\
\hline Partovia III (11) & 64 & 35 & 35 & 64 & 75 & 40 & I \\
\hline Gran Balneario (12) & 101 & 73 & 45 & 78 & 98 & 71 & II \\
\hline $\operatorname{Arcos}(13)$ & 85 & 54 & 45 & 75 & 87 & 56 & I \\
\hline O Xardín (14) & 65 & 40 & 65 & 73 & 65 & 33 & I \\
\hline Laias $(15)$ & 100 & 75 & 85 & 110 & 102 & 72 & II \\
\hline
\end{tabular}

Table 4. Values of the saturation index for various mineral species using the PHREEQE (Parkust et al., 1980) code.

\begin{tabular}{lrrrrrrrrrrrrrrrr}
\hline Sample No & 1 & 2 & 3 & 4 & 5 & 6 & 7 & 8 & 9 & 10 & 11 & 12 & 13 & 14 \\
\hline Chalcedony & 0.220 & 0.340 & 0.260 & 0.320 & 0.650 & 0.240 & 0.030 & 0.080 & -0.100 & 0.060 & 0.110 & 0.400 & 0.340 & 0.240 & 0.250 \\
Quartz & 0.660 & 0.800 & 0.680 & 0.710 & 0.760 & 0.620 & 0.420 & 0.510 & 0.290 & 0.470 & 0.540 & 0.820 & 0.800 & 0.710 & 0.620 \\
Calcite & -1.04 & -2.57 & -1.48 & 0.220 & -0.240 & -0.350 & 0.510 & -0.600 & 0.280 & 0.230 & 0.060 & -0.110 & -0.130 & -1.48 & -0.530 \\
Kaolite & 8.94 & 3.58 & 8.85 & 0.640 & 2.27 & 0.850 & -0.440 & 2.91 & -0.380 & 0.630 & 1.01 & 1.46 & 2.20 & 3.42 & 3.45 \\
k-mica & 15.7 & 6.39 & 15.2 & 4.60 & 6.40 & 4.56 & 3.31 & 6.43 & 2.92 & 4.22 & 4.63 & 5.51 & 6.65 & 6.10 & 7.36 \\
\hline
\end{tabular}

be used as an indicator of the residence time (Edmunds and Smedley, 2000; Sánchez-Martoset al., 2004). Moreover, Leemanand Sisson (1996) found boron in very different geological environments, associated with the presence of volcanic rocks, geothermal processes, and with materials deposited in very saline environments. Because it is highly soluble, it tends to concentrate in environments that have a limited water circulation, like in evaporites or brines of marine or continental origin (Uhlman, 1991). Other authors consider that the elevated boron concentration in some connate waters is directly related to the content of $\mathrm{K}, \mathrm{Li}, \mathrm{Mg}, \mathrm{Sr}$ and I (Macpherson and Land., 1989). The high values recorded in thermal waters may be due to the alteration of volcanic rocks and hydrothermal activity (Risacher, 1984; Risacher and Fritz, 1991). In this respect the influence of temperature on its liberation has been noted (Arnorsson and Andresdottir., 1995). In order to find relationships between a set of the main compositional variables (variables $X)$ and Li or B $(Y$ variable) for data obtained from the selected water samples, PLS-R was chosen. The selected algorithm was able to correlate a block of $X$ variables with $\mathrm{Li}$, giving an $r^{2}$ of 0.9988 for a model with two principal components and 0.8996 with $B$ variable. Figure 4 shows partial squares regression plots.
The obtained results show a clear separation, based on the first two principal components, between clusters I and II. In cluster I the samples 1, 2, 3, 8, 9, 10, 11, 13 and 14 with lower $\mathrm{Li}$ and $\mathrm{B}$ content were grouping. In cluster II the samples 4, 5, 6, 7 and 15 with higher Li and B content were grouped. The same clusters were determined by PCA with the same distribution and therefore, the same results were found for both analysis. It was proven that samples of cluster I were the youngest ones or water samples of diverse origin that could be mixed successively. Nevertheless, the samples with longest water-rock contact time were found in cluster II.

\subsection{Geothermometer results}

One of the most important applications of geochemistry for geothermal resources is using chemical geothermometers to give valuable information about what is happening in the reservoir. The accuracy of a geothermometer application is based on two assumptions. The basic assumption is that a temperature-dependent equilibrium is attained between fluid and minerals in the reservoir. It is further assumed that the composition of a fluid is not affected by chemical reactions in the upflow of geothermal system zones where cooling occurs 

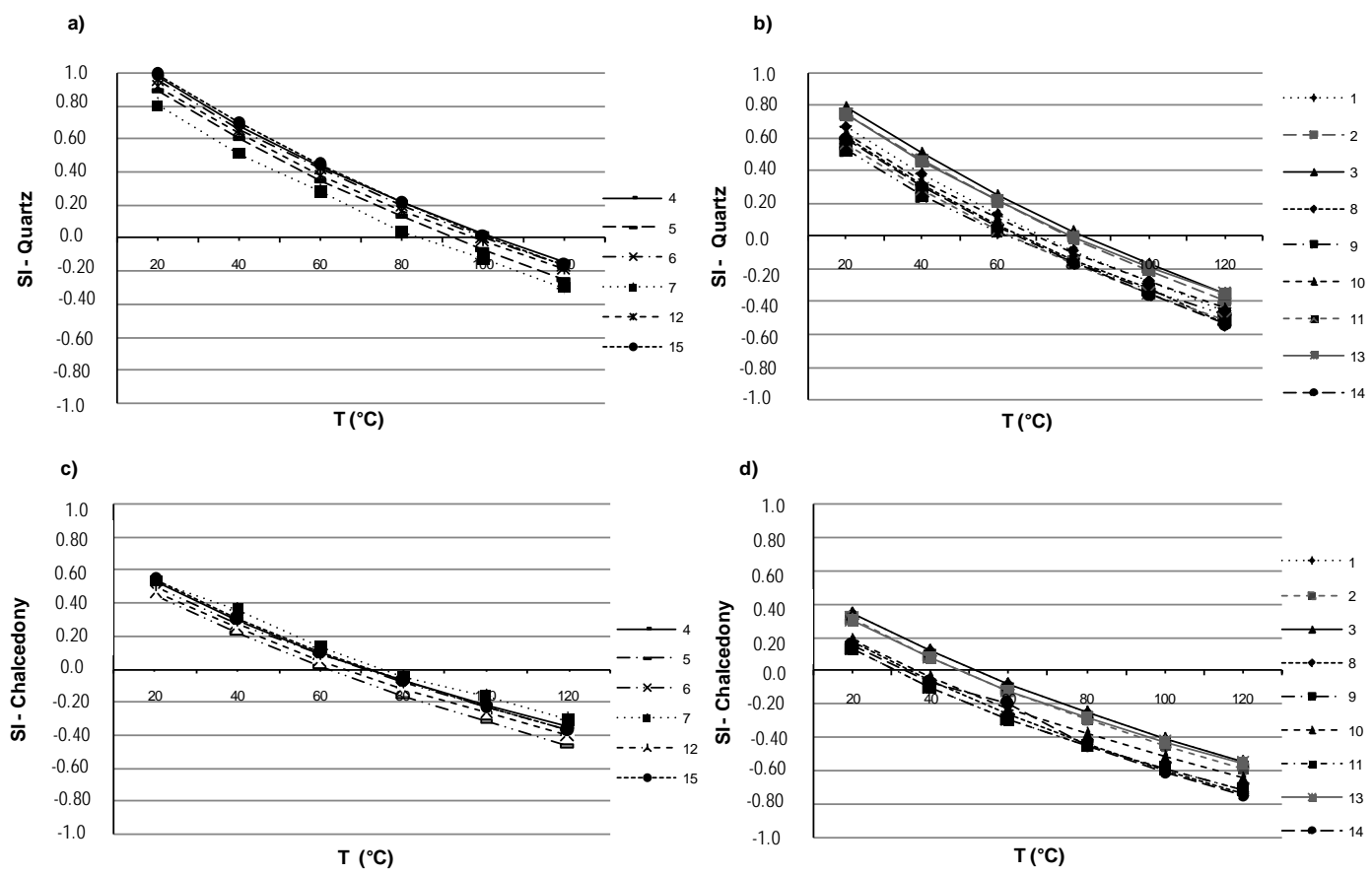

Fig. 5. Result of the geothermometric simulations: (a) quartz saturation index for the samples with equilibrium temperature between $85-$ $110^{\circ} \mathrm{C}$, (b) Quartz saturation index for the samples with equilibrium temperatures between $63-85^{\circ} \mathrm{C}$, (c) Chalcedony saturation index for the samples with equilibrium temperatures between $45-85^{\circ} \mathrm{C}$, (d) Chalcedony saturation index for the samples with equilibrium temperatures between $35-65^{\circ} \mathrm{C}$.

(Wei, 2006). Various geothermometers have been developed to predict reservoir temperatures in the geothermal system (Tole et al., 1993). Geothermometers that have provided better results for these alkaline systems were those based on dissolved silica $\left(\mathrm{SiO}_{2}\right.$-chalcedony or $\mathrm{SiO}_{2}$-quartz) and $\mathrm{Na}$ $\mathrm{K}$. These two techniques reflect the state of thermal equilibrium solutions of these systems with respect to quartzchalcedony-albite, and potassium felspar, respectively. In the present work, a silica geothermometer was chosen due to the geochemical setting of Galicia.

Table 3 shows the equilibrium temperatures for quartz, chalcedony, kaolinite and k-mica. The chalcedony and/or quartz equilibrium temperatures are also presented for comparison. As can be shown, the calculated temperatures for the silicaquartz and chalcedony geothermometers are in the range from 65 to $102^{\circ} \mathrm{C}$ and from 33 to $72^{\circ} \mathrm{C}$, respectively. It could be deduced from these results that quartz is the mineral phase, which rules the equilibrium state of the silica, as it was previously reported by Michard (1990), when he studied the behaviour of several elements in deep hot waters from granitic areas of Europe.

Two groups could be distinguished through the results obtained for both geothermometers. The first group would be integrated by the thermal waters, which reached the equilibrium at lowest temperatures (between $70-87^{\circ} \mathrm{C}$ for the quartz geothermometer and between $33-56^{\circ} \mathrm{C}$ for the chalcedony geothermometer) and can be shown in Table 3 in- cluded the samples $1,2,3,8,9,10,11,13$ and 14. The second group formed by the thermal waters $4,5,6,7,12$ and 15 , that reached the equilibrium at highest temperatures (between 92-102 for the quartz the geothermometer and between $62-72{ }^{\circ} \mathrm{C}$ for the chalcedony geothermometer). All of these results agree with the previous obtained by PCA and PLSR, where also two groups were found. In group I the selected water samples could be in contact with surface waters and therefore, the residence time in the reservoir and the water-rock interaction would be less important than for the thermal waters of group II.

\subsection{Hydrogeochemical modelling}

Geothermometers are based on the assumption that specific temperature-dependent mineral-solution equilibria are attained in the geothermal reservoir. Nevertheless, it is also advisable to study the fluid saturation equilibrium with the hydrothermal minerals in the reservoir (Reed and Spycher, 1984). In order to know the state of this equilibrium, saturation index (SI) was used and is the logarithm of the ratio (at each temperature) between the solubility product of a certain mineral by hydrolytical reaction $(Q)$ and its equilibrium constant $(K)$. In this way, the inter-relationship between the lithologies encountered around the waters and their chemical composition could also be explained. All minerals in equilibrium at the same temperature converge to $\mathrm{SI}=0 ; \mathrm{SI}<0$ for 
an undersaturated solution, and SI $>0$ for a supersaturated solution. In the present work, chalcedony, quartz, calcite, kaolinite and k-mica were selected to calculate the equilibrium state for the selected thermal waters. Table 4 presents the SI for the selected minerals, calculated at the $\mathrm{pH}$ and temperature measured in the field. The studied waters are saturated with respect to quartz, k-mica, chalcedony and kaolinite, with the exception of Cortegada Baños and Partovia I. Other authors (López-Chicano et al., 2001) have also observed super-saturation with respect to quartz in geothermal fluids in Southern Spain. The lower saturation indices observed for chalcedony could be explained by the lower water solubility. The thermal waters $1,2,3,5,6,8,12,13,14$ and 15 are under-saturated with respect to calcite whereas the samples 4, 7, 9, 10 and 11 are super-saturated with respect to the same mineral, which is probably due to the cationic change of these thermal waters (D'Amore et al., 1987). Instead, the highest saturation index for kaolinite and K-mica could only be the result of a preferential circulation through felspar and mica.

In Fig. 5 shows the variation of saturation indices SI with temperature for quartz and chalcedony and kaolinite phases, considering a temperature interval between $20^{\circ} \mathrm{C}$ and $120^{\circ} \mathrm{C}$. The intersection of SI curves at zero saturation index gives the equilibrium temperature (D'amore et al., 1987; Tole et al., 1993; López-Chicano et al., 2001). In this way, two groups could also be distinguished through the results obtained depending on the reservoir temperatures for the selected thermal waters. A group formed by the thermal waters, which reach the state of equilibrium at the highest temperatures, between 85 and $110^{\circ} \mathrm{C}$ (Fig. 5a) for quartz phases, and between 45 and $85^{\circ} \mathrm{C}$ (Fig. 5c) for chalcedony and kaolinite phases. These thermal waters correspond to the samples 4, 5, 6, 7, 12 and 15 . The rest of the selected thermal waters would reach the state of equilibrium at the lowest temperatures between, $63^{\circ} \mathrm{C}$ and $85^{\circ} \mathrm{C}$ (Fig. 5b) for the quartz phase, and between $35^{\circ} \mathrm{C}$ and $65^{\circ} \mathrm{C}$ (Fig. 5d) for the chalcedony and kaolinite saturation indices. SI obtained for these samples could depend on re-equilibrium processes during the ascent of the fluid towards the surface.

\section{Conclusions}

In this paper the chemistry of major and trace inorganic elements in 15 thermal waters discharging in the council of Carballiño (province of Ourense) were presented and discussed. The results of the hydrogeochemistry analysis showed one main water family of bicarbonated water of sodium type. Graphical representations of $\mathrm{Cl}^{-} / \mathrm{SO}_{4}^{-2}$, $\mathrm{Cl}^{-} / \mathrm{HCO}_{3}^{-}$and $\left(\mathrm{Cl}^{-}+\mathrm{SO}_{4}^{-2}\right) / \mathrm{HCO}_{3}^{-}$ratios showed waterrock interactions. These results were obtained through PCA and PLSR and the samples were grouped in two clusters as a function of water age and depth. Results from the geothermometric modelling as well as of geothermometersalso agreed with the findings from the previous analyses and also revealed two groups. A first group formed by thermal waters that reach the equilibrium at highest temperatures (between 85 and $110^{\circ} \mathrm{C}$ for quartz IS and between 92 and $102^{\circ} \mathrm{C}$ for the quartz geothermometer, and between 45 and $85^{\circ} \mathrm{C}$ for chalcedony IS, and between 62 and $72^{\circ} \mathrm{C}$ for the chalcedony geothermometer), which are under-saturated with respect to calcite. The second group of thermal waters would reach the equilibrium at lowest temperatures (between 63 and $85^{\circ} \mathrm{C}$ for quartz IS and 70 and $87^{\circ} \mathrm{C}$ for the quartz geothermometer, and between $35-65^{\circ} \mathrm{C}$ for chalcedony IS and, between $33-56^{\circ} \mathrm{C}$ for the chalcedony geothermometer) and are super-saturated with respect to calcite. Comparable results were obtained for equilibrium temperatures obtained through modelling of the equilibrium states and by geothermometers with an error band of $\pm 10^{\circ} \mathrm{C}$.

Edited by: L. Pfister

\section{References}

Arnorsson, S. and Andresdottir, A.: Process controlling the distribution of boron and chlorine in natural waters in Iceland, Geochim. Cosmochim. Ac., 59, 4125-4146, 1995.

Ball, J. W. and Nordstrom, D. K.: User's manual for WATEQ4F, with revised thermodynamic data base and test cases for calculating speciation of major, trace, and redox elements in natural waters, US Geological Survey Open File Report 91-183, USA, 2001.

Brondi, M., Dall'Aglio, M. D., and Vitrano, F.: Lithium as pathfinder element in the large scale hydrochemical exploration for hydrothermal systems, Geothermics, 283, 142-153, 1973.

Brondi, M., Fidelibus, M. D., Gragnan, I. R., and Tulipano, L.: Hydrochemical study and distribution of some trace elements in the most important coastal springs and groundwater of the Apulian Region (Southern Italy), Geologia Applicatta et Idrogeologia, XVII, 65-80, 1983.

Camo Process: available online at: www.camo.no, last access: last access: January 2012, 2004.

Cerón, J. C., Pulido-Bosch, A., and Bakalowicz, M.:Application of principal components analysis to the study of $\mathrm{CO}_{2}$-rich thermomineral waters in the aquifer system of alto guadalentín (Spain), Hydrolog. Sci. J., 44, 929-942, 1999.

Chan, L., Gieskes, J. M., You, C., and Edmond, J. M.: Lithium isotope geochemistry of sediments and hydrothermal fluids of the Guaymas Basin, Gulf of California, Geochim. Cosmochim. Ac., 58, 4443-4454, 1994.

Chebotarev, I. I. : Metamorphism of natural water in the crust of weathering I,II,\& III, Geochim. Cosmochim. Ac., 8, 22-212, 1955.

Cruz, J. V. and França, Z.: Hydrogeochemistry of thermal and mineral waters springs of the azores archipielago (Portugal), J. Volcanol. Geoth. Res., 151, 382-398, 2006.

D'Amore, F., Fancelli, R., and Caboi, R.: Observation on the application of chemical geothermometers to some hydrothermal systems in Sardinia, Geothermics, 16, 271-282, 1987. 
Delgado-Outeiriño, I., Araujo-Nespereira, P., Cid-Fernández, J. A., Mejuto, J. C., Martínez-Carballo, E., and Simal-Gándara, J.: Behaviour of thermal waters through granite rocks based on residence time and inorganic pattern, J. Hydrol., 373, 329-336, 2009.

Dirección Xeral de Industria, Enerxía e Minas: Cluster das augas minerais e termais de Galicia, Xunta de Galicia, Consellería de Innovación, Industria e Comercio, 2003.

Edmunds, W. M. and Smedley, P. L.: Residence time indicators in groundwater: the East Midlands Triassic sand stone aquifer, Appl. Geochem., 15, 737-752, 2000.

Fidelibus, M. D. and Tulipano, L.: Major and minor ions as natural tracers in mixing phenomena in coastal carbonate aquifers of the Apulia, in: Proc. of the 11th Salt Water Intrusion Meeting, edited by: Kozerski, B. and Sadurski, A., Gandsk, 283-293, 1990.

González-Barreiro, C., Cancho-Grande, B., Araujo-Nespereira, P., Cid-Fernández, J. A., and Simal-Gándara, J.: Occurrence of soluble organic compounds in thermal waters by ion-trap mass detection, Chemosphere, 75, 34-47, 2009.

López-Chicano, M., Cerón. J.C., Vallejos, A., and Pulido-Bosch, A.: Geochemistry of thermal springs, Alhama de Granada (southern Spain), Appl. Geochem., 16, 1153-1163, 2001.

Leeman, W. P. and Sisson, V. B.: Geochemistry of Boron and Its Implications for Crustal and Mantle Processes, Rev. Mineral.,33, 645-707, 1996.

Macpherson, G. L. and Land, L. S.: Boron in saline brines in Gulf of Mexico sedimentary basin, USA, in: the Proc. 6th Internatl, edited by: Balkema, A. A., Sympos, OnWater-Rock Interaction, 457-460, 1989.

Michard, G.: Behaviour of major elements and some trace elements ( $\mathrm{Li}, \mathrm{Rb}, \mathrm{Cs}, \mathrm{Sr}, \mathrm{Fe}, \mathrm{Mn}, \mathrm{W}$ y F) in deep hot waters from granitic areas, Chem. Geol., 89, 117-134, 1990.
Parkhurst, D. L., Thorstenson D. C., and Plummer, L. N.: PHREEQE - a computer program for geochemical calculations, US Geol. Surv., Water Resour. Invest. 80-96, 1980.

Piper A. M.: A graphic procedure in the geochemical interpretation of water analysis, American Geophysical Union Trans, 25, 914 923, 1944.

Reed, M. and Spycher, N.: Calculation of $\mathrm{pH}$ and mineral equilibria in hydrothermal waters with application to geothermometry and studies of boiling and dilution, Geochim. Cosmochim. Ac., 48, 1479-1492, 1984.

Regional Government of Galicia: International Congress on Thermal Tourism Sustainability, Health, Quality and Promotion, In the pursuit of innovation in the thermal sector, available at: http: //www.congresoturismotermal.com/conclusiones.html, last access: October 2011, 2011.

Risacher, F.: Origine des concentrations extremes en bore et lithium dans Saumeres de L'Altiplano Bolivien, C. R. Acad. Sci. Paris, 299, 701-708, 1984.

Risacher, F. and Fritz, B.: Geochemistry of Bolivian salars, Lipez, southern Altiplano: origin of solutes and brine evolution, Geochim. Cosmochim. Acta, 55, 687-705, 1991.

Sánchez-Martos, F., Pulido Bosch, A., Vallejos, A., Molina, L., and Gosbert, J.: Rasgos hidrogeoquímicos de las aguas termales en los acuíferos carbonatados del bajo andarax (almería), Geogaceta, 35, 171-174, 2004.

Tole, M. P., Armannsson, H., Pang, Z.-H., and Arnórsson, A.: Fluid/mineral equilibrium calculations for geothermal fluids and chemical geothermometry, Geothermics, 22, 17-37, 1993.

Uhlman, K.: The geochemistry of boron in a landfill monitoring program, Ground Water Monitoring Review, 11, 139-143, 1991.

Wei, W.: Geothermical study of the Xianyang low-temperature geothermal field, Shaanxi Province, China, Geothermal Training Programme, 22, 510-522, 2006. 